\title{
Friction and Wear Behaviors of Al/Epoxy Composites during Reciprocating Sliding Tests
}

Alessandro Ruggiero ${ }^{1}$, Petr Valášek ${ }^{2}$, Massimiliano Merola ${ }^{1}$

${ }^{1}$ Department of Industrial Engineering, University of Salerno, Via Giovanni Paolo II, 132, 84084 Fisciano, Salerno, Italy.

E-mail: ruggiero@unisa.it,mmerola@unisa.it

${ }^{2}$ Department of Material Science and Manufacturing Technology, Faculty of Engineering, Czech University of Life Sciences Prague. Kamýcká 129, 165 21, Prague. Czech Republic. E-mail: valasekp@tf.czu.cz

\begin{abstract}
Aluminium is widely represented material in engineering - one of the possible forms of application is an Al powder, when mutual interaction mainly with polymer matrix creates new materials. In practice, the aluminium powder is commonly used together with a number of reaction resins, e.g. epoxy resins. Such systems can be described as liquid metals, and amongst other options of the application, they are used for quick renovation of the functional areas of machines. In such applications, particularly important are hardness and durability of the composite layer against wear. This paper experimentally evaluate the friction and wear of systems based on epoxy resin with aluminium powder (microparticles), through reciprocating sliding tribotests. Tribological outcomes evidenced a reduction of the friction coefficient when the resin is reinforced by alumium particles, with a concentration of $32 \%$ in term of volume fraction.
\end{abstract}

Keywords: Aluminium, composite, hardness, reactive resin, tribology.

\section{Acknowledgement}

The results were supported by the grant IGA TF 2015 (31140/1312/3107): Optimizing of the properties of resins and adhesives filled with organic and anorganic microparticles determined with experimental approach.

\section{References}

[1] SATAPATHY, B.K., BIJWE, J. (2002). Analysis of simultaneous influence of operating variables on abrasive wear of phenolic composites. In: Wear, Vol. 253, pp. 787 - 794.

[2] VALÁŠEK, P., MÜLLER, M. (2013). Polyurethane resins filled with inorganic waste particles. In: Manufacturing Technology, Vol. 13, No. 2, pp. $241-247$.

[3] VALÁŠEK, P., MÜLLER, M. (2012). Polymeric particle composites with filler saturated matrix. In: Manufacturing Technology, Vol. 12, No. 13, pp. 272 - 276.

[4] MÜLLER, M., VALÁŠEK, P. (2012). Abrasive wear effect on Polyethylene, Polyamide 6 and polymeric particle composites. In: Manufacturing Technology, Vol. 12, pp. 55 - 59.

[5] GORBATKINA, YU.A., IVANOVA-MUMZHIEVA, V.G., UL'YANOVA, T.M. (2007). Adhesiveness of an epoxy oligomer filled with aluminum oxide powders. In: Polymer Science, Vol. 49, No. 2, pp. 131 - 134.

[6] SHIGUO, D., ET AL. (2005). Surface modification of $\mathrm{Al}_{2} \mathrm{O}_{3}$ fine powders and application in epoxy resin. In: Key Engineering Materials. pp. 1033 - 1034.

[7] KAHRAMANA, R., MEHMET SUNARB, BEKIR YILBAS. (2008). Influence of adhesive thickness and filler content on the mechanical performance of aluminum single-lap joints bonded with aluminum powder filled epoxy adhesive. In: Materials Science Forum, Vol. 205, 2008, pp. 183 - 189.

[8] CZICHOS, H. (1978). Tribology. A systems approach to the science and technology of friction, lubrication and wear. Elsevier Scientific Publishing Co.

[9] RUGGIERO, A., MEROLA, M., CARLONE, P., ARCHODOULAKI, V.M. (2015). Tribo-mechanical characterization of reinforced epoxy resin under dry and lubricated contact conditions. In: Composite Part B, Engineering, Vol. 79, pp. $595-603$.

[10]MEROLA, M., CARLONE, P., RUGGIERO, A., ARCHODOULAKI, V.-M. (2015). Mechanical and tribological characterization of composite laminates manufactured by liquid composite molding processes. In: Key Engineering Materials, Vols. 651-653, pp. 907 - 912.

[11]SCHELLING, A., KAUSCH, H. (1993). Reciprocating Dry Friction and Wear of Short Fibre Reinforced Polymer Composites, in: K. Friedrich (Ed.), In: Advances in Composite Tribology, Elsevier Science, Amsterdam, 1993, pp. $65-105$. 
[12]RUGgiero, A., D'AMATO, R., GÓMEZ, E. (2015). Experimental analysis of tribological behavior of UHMWPE against AISI420C and against TiAl6V4 alloy under dry and lubricated conditions. In: Tribology International, Vol. 92, pp. $154-161$.

[13]JABER, S.A., RUGGIERO, A., BATTAGLIA, S., AFFATATO, S. (2015). On the roughness measurement on knee prostheses. In: International Journal of Artificial Organs. Vol. 38, No. 1, pp. 39 - 44.

[14]HREHA, P., RADVANSKÁ, A., CÁRACH, J., LEHOCKÁ, D., MONKOVÁ, K., KROLCZYK, G., RUGGIERO, A., SAMARDZIĆ, I., KOZAK, D., HLOCH, S. (2014). Monitoring of focusing tube wear during abrasive waterjet (AWJ) cutting. In: Metalurgija, Vol. 53, pp. 533-536.

[15]VALÁŠEK, P., MÜLLER, M. (2013). Polymeric composite based on glass powder - Usage possibilities in agrocomplex. In: Scientia Agriculturae Bohemica, Vol. 2, pp. 107 - 112.

[16]MÜLLER, M. (2013). Research of renovation possibility of machine tools damage by adhesive bonding technology. In: Manufacturing Technology, Vol. 13, No. 4, pp. 504 - 509.

[17]NOVÁK, M. (2011). Surface duality hardened steels after grinding. In: Manufacturing technology, Vol. 11, pp. $55-59$.

[18]RUDAWSKA, A. (2014). Selected aspects of the effect of mechanical treatment on surface roughness and adhesive joint strength of steel sheets. In: International Journal of Adhesion and Adhesives, Vol. 50, pp. 253 - 243.

[19]ŤAVODOÁ, M. (2013). The surface quality of materials after cutting by abrasive water jet evaluated by selected methods. In: Manufacturing Technology, Vol. 13, No. 2, pp. 236 - 241. 